\title{
RADIOCARBON RESERVOIR AGES IN THE GULF OF CALIFORNIA: ROLES OF UPWELLING AND FLOW FROM THE COLORADO RIVER
}

\section{GLENN A. GOODFRIEND}

Geophysical Laboratory, Carnegie Institution of Washington, 5251 Broad Branch Rd., N.W. Washington, D.C. 20015 USA

and

\section{KARL W. FLESSA}

Department of Geosciences, The University of Arizona, Tucson, Arizona 85721 USA

\begin{abstract}
We measured apparent radiocarbon ages of live-collected, pre-bomb mollusk shells from the northern and central Gulf of California to determine the source of the reservoir ages and the reservoir age correction offsets for calibrating ${ }^{14} \mathrm{C}$ dates of fossil samples. Reservoir ages average $860 \mathrm{yr}$ in the northern Gulf and $725 \mathrm{yr}$ in the central Gulf. The corresponding $\Delta R$ values (the deviation from typical worldwide values) are $540 \mathrm{yr}$ and $395 \mathrm{yr}$, respectively, with variabilities (SD) of 90 and $110 \mathrm{yr}$. This variability significantly limits the precision of calibrated ${ }^{14} \mathrm{C}$ ages. The apparent ${ }^{14} \mathrm{C}$ age of Colorado River water (as measured in a freshwater mussel, collected in the 1890 s, before diversion of river flow) is not sufficiently high (1420 yr) to account for the high reservoir ages in the Gulf. The lack of a relation between the stable isotope composition of Gulf mollusks and their reservoir ages is further evidence that the Colorado River does not make a significant contribution to Gulf reservoir ages. Upwelling of old, deep Pacific-derived water appears to be the cause of the large reservoir ages.
\end{abstract}

\section{INTRODUCTION}

Several factors contribute to the apparent radiocarbon age of inorganic carbon in marine waters (the marine ${ }^{14} \mathrm{C}$ reservoir age), which averages $c a .400 \mathrm{yr}$ worldwide (Stuiver, Pearson and Braziunas 1986). In deep ocean waters, and in areas where such waters upwell, large reservoir ages occur because of the long residence time of carbon in the bicarbonate pool. So, in upwelling areas such as the California coast (Berger, Taylor and Libby 1966) or the Pacific coast of South America (Taylor and Berger 1967), reservoir ages are higher than average. In addition, continental waters may contribute hardwater effects (from the dissolution of limestone); their input into marine waters via either rivers (Little 1993) or groundwater (Heier-Nielsen et al. 1995) may increase ${ }^{14} \mathrm{C}$ reservoir ages. In Arctic areas, stratification of marine waters and ice cover reduces exchange with the atmosphere and thus results in higher reservoir ages (Mangerud and Gulliksen 1975).

Large ${ }^{14} \mathrm{C}$ reservoir ages were first recognized in the Gulf of California based on analyses of two pre-bomb shell samples from the central Gulf by Berger, Taylor and Libby (1966), who suggested that upwelling of old Pacific water into the Gulf was likely responsible. However, shells collected alive in 1962 from the northern end of the Gulf showed apparent ages of only 210 and $270 \mathrm{yr}$ (Hubbs, Bien and Suess 1965: 70), significantly lower than typical marine reservoir ages. Berger, Taylor and Libby (1966) concluded that these analyses indicated the lack of upwelling in the northern Gulf. However, subsequent studies have shown that by 1962 , a measurable amount of the excess ${ }^{14} \mathrm{C}$ produced by thermonuclear bomb tests had already entered the world oceans (Druffel 1987, 1997; Weidman and Jones 1993). The presence of bomb carbon is therefore a likely explanation for the low apparent ages of the two northern Gulf mollusk samples.

The Gulf of California is known to be an area of significant upwelling (Roden 1964). Winds blow largely from the north or northwest along the axis of the Gulf, pushing surface water out the entrance of the Gulf in the south and sucking in water from depth to compensate. The entrance of the Gulf is $>2000 \mathrm{~m}$ deep (Fig. 1), which permits relatively old Pacific bottom waters to be brought into the 


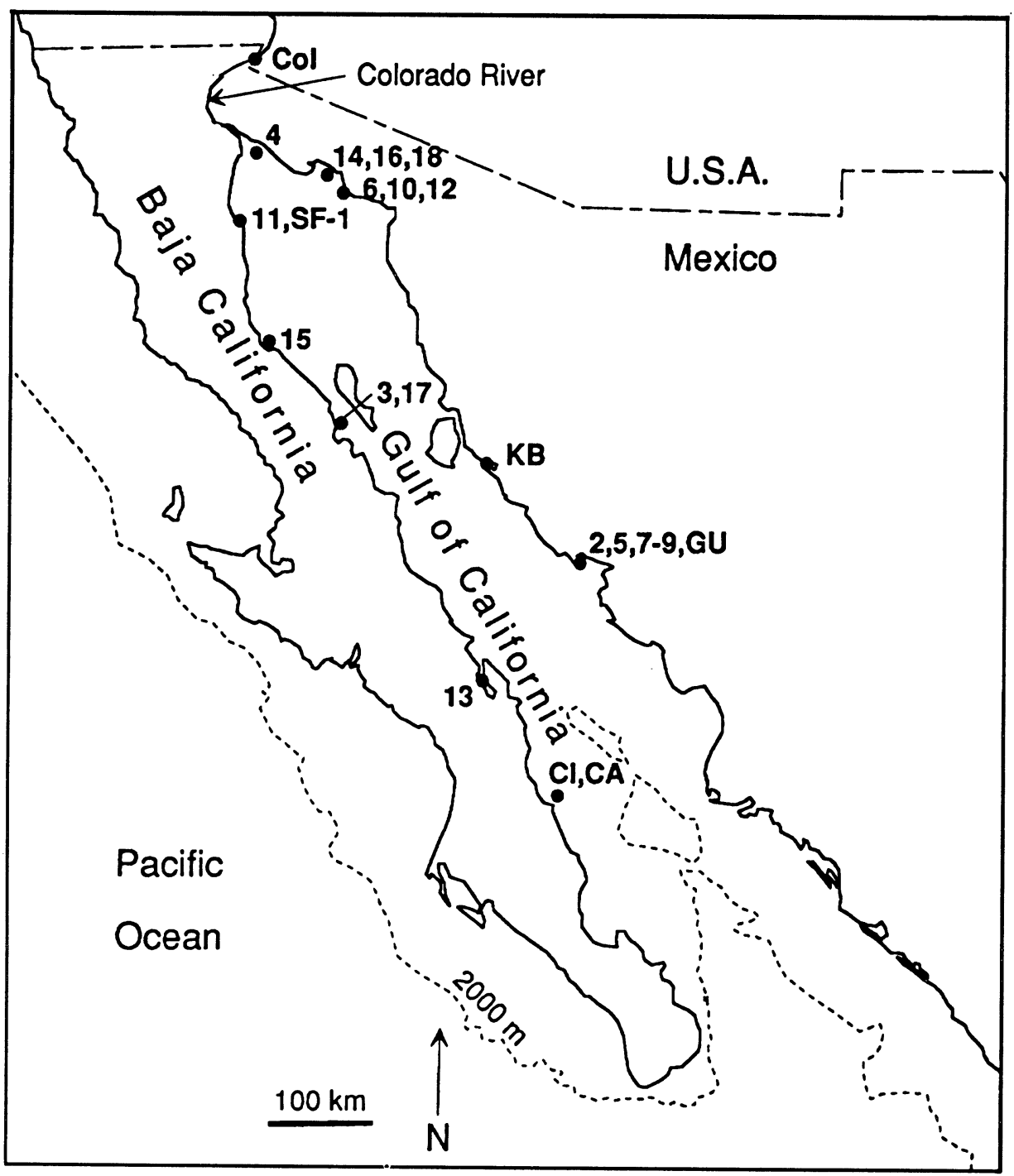

Fig. 1. Map of the Gulf of California and surrounding region, showing location of sample sites (Mod- numbers and letter abbreviations are listed in Table 1 ) and $2000 \mathrm{~m}$ isobath

Gulf. In the northern Gulf, the large tidal range (up to $10 \mathrm{~m}$; Thompson 1968) favors mixing of surface waters. Overturn of surface waters (down to $100 \mathrm{~m}$ ) may occur during the winter (Roden 1964).

The Colorado River no longer flows into the Gulf, except during unusual flood events. All the water is now diverted for human use before it reaches the sea. Substantial diversion of Colorado River water to the Imperial Valley, California, began in 1901 and was followed in 1905 by the accidental diversion of the entire flow of the river into the Salton Sea, which continued until 1907. Upstream dams and diversions were subsequently built to control and divert the river's flow. The completion of Hoover Dam in 1935 and subsequent irrigation projects in the Imperial Valley significantly decreased the river's flow at the Mexican border. Mexican agriculture utilizes the entire 1.5 million 
acre-feet $\left(=1.85 \times 10^{9} \mathrm{~m}^{3}\right)$ per year (10\% of the river's estimated virgin flow) allocated to it under international treaty. (See Fradkin (1984) for the history of the river's modification and use.)

In the present study, we analyzed apparent ${ }^{14} \mathrm{C}$ ages in pre-bomb live-collected clams from the northern and central regions of the Gulf of California (Fig. 1) in order to assess ${ }^{14} \mathrm{C}$ reservoir ages within the Gulf and their spatial and temporal variation. To evaluate the possible influence of Colorado River flow on the reservoir ages of Gulf waters, we also analyzed the stable isotope composition of these shells and determined the apparent ${ }^{14} \mathrm{C}$ age and stable isotope composition of Colorado River water bicarbonate (before extensive diversion of the river) through analysis of a sample of late 19th-century freshwater mussel shell from the river. If flow from the Colorado River were a significant influence on reservoir ages, then a correlation between reservoir ages and both $\delta^{18} \mathrm{O}$ and $\delta^{13} \mathrm{C}$ values would be expected, since the river water is quite depleted in both ${ }^{18} \mathrm{O}$ and ${ }^{13} \mathrm{C}$ compared to marine water (Keith, Anderson and Eichler 1964).

\section{MATERIALS AND METHODS}

Specimens of articulated bivalve shells from the Gulf of California and the Colorado River were obtained from the U.S. National Museum of Natural History (Washington, D.C.), the California Academy of Sciences (San Francisco), the Los Angeles County Museum, and the San Diego Museum of Natural History. In addition, we used published ${ }^{14} \mathrm{C}$ data for five shell samples (Berger, Taylor and Libby 1966; Flessa, Cutler and Meldahl 1993; Ingram and Southon 1997). In all, ${ }^{14} \mathrm{C}$ ages of 8 specimens from the northern Gulf and 12 specimens from the central Gulf were obtained (Fig. 1).

Our specimen Mod-3 is noteworthy for historical and literary reasons. This specimen of Chione californiensis is from the Ricketts collection, now housed in the National Museum of Natural History. It is undoubtedly one of the specimens mentioned by John Steinbeck in his description of his and Ricketts's work in Angeles Bay (Bahía de los Ángeles) on April 1, 1940: "We ... then took the skiff to the sand flats on the northern side of the bay. It was hard, compact mud sand with a long shallow beach, and it was heavy and difficult to dig into. We took there a number of Chione and Tivela clams and one poor half-dead amphioxus" (Steinbeck 1986: 262).

Radiocarbon and stable isotope analyses were carried out on shell pieces cut in a wedge from the growth edge of the shells using a Dremel motorized tool with a 1-inch $(2.5 \mathrm{~cm})$ diameter circular saw blade. Cuts $c a .1 \mathrm{~cm}$ deep were made to ensure that an average value, rather than a seasonally biased one, was obtained. Radiocarbon analyses were carried out by accelerator mass spectrometry (AMS) at the NSF-Arizona AMS Facility at the University of Arizona, Tucson. Stable isotope analyses were carried out in the laboratory of Dr. K. C. Lohmann at the University of Michigan, Ann Arbor.

\section{RADIOCARBON RESERVOIR AGES IN THE GULF}

Apparent ${ }^{14} \mathrm{C}$ ages of the Gulf mollusk samples are presented in Table 1. Radiocarbon reservoir ages ( $\mathrm{R}$; Table 1) were calculated as the difference between the measured ${ }^{14} \mathrm{C}$ age and the ${ }^{14} \mathrm{C}$ age of atmospheric $\mathrm{CO}_{2}$ contemporary with each of the samples (Stuiver and Braziunas 1993). For both the northern and central Gulf, a wide range of reservoir ages was obtained (230 to $960 \mathrm{yr}$ ).

One specimen (sample Mod-14), collected in 1956, has an anomalously low reservoir age. One possible explanation is that some bomb ${ }^{14} \mathrm{C}$ reached the sample. Annual records of ${ }^{14} \mathrm{C}$ in corals at Fanning Island in the Pacific $\left(4^{\circ} \mathrm{N}, 159^{\circ} \mathrm{W}\right)$ show that bomb carbon was first detected in 1958 (Druffel 


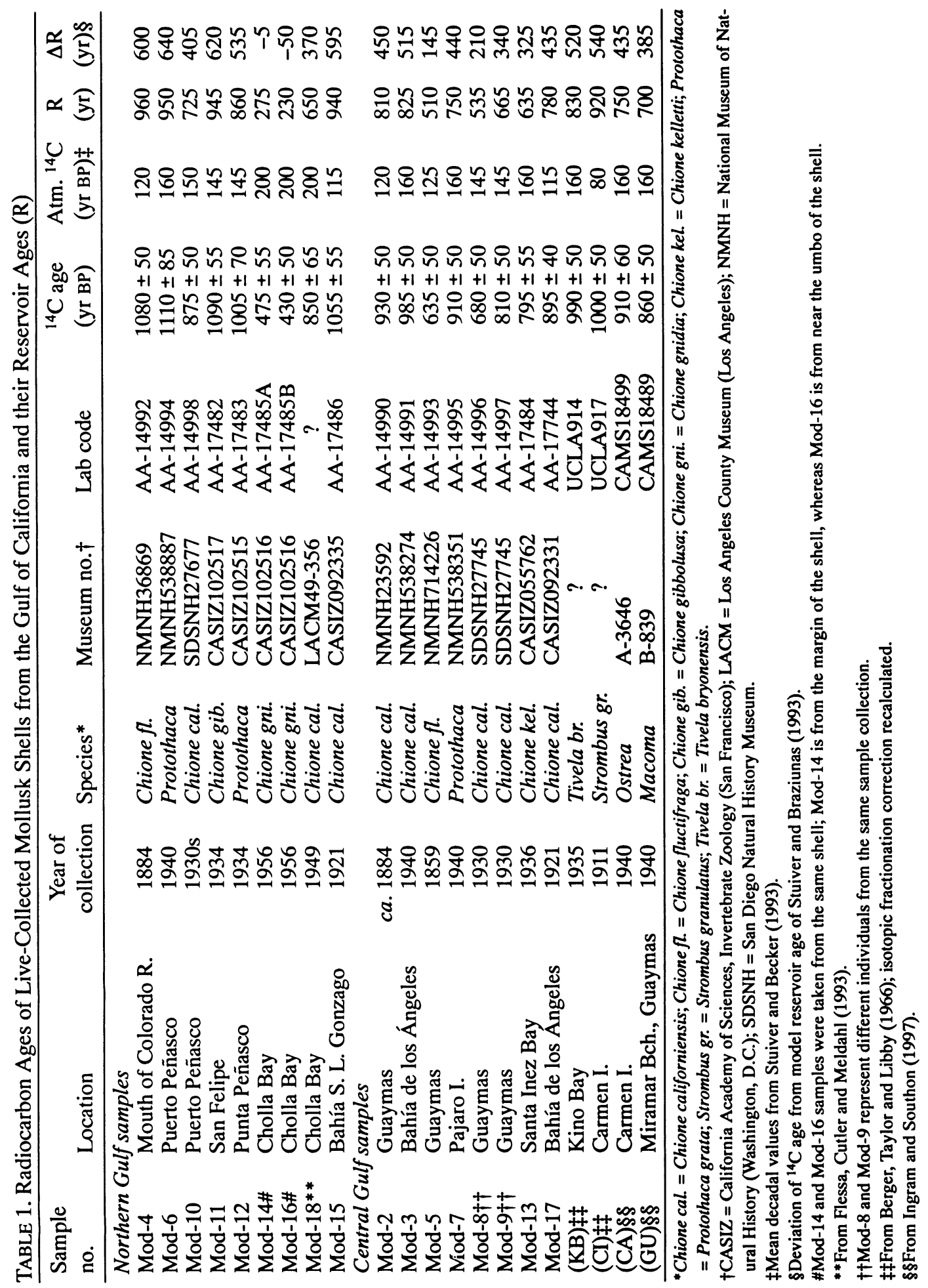


1987). However, some spatial variation in the timing of the bomb spike may be expected (cf. the record for Uva Island; Druffel 1987). A second sample of the shell (Mod-16), from earlier growth near the umbo, was also analyzed. This older portion of the shell should have been laid down at least a year or two earlier, when the influence of bomb carbon is even less likely. The similarly low reservoir age obtained for this sample suggests that bomb ${ }^{14} \mathrm{C}$ is not a likely explanation. Possibly this specimen lived at a time when unusual storm activity resulted in enhanced mixing of atmospheric carbon into the northern coastal Gulf waters. Because of uncertainties regarding the unusual value of this specimen, it is left out of further consideration of reservoir ages. However, it does raise the possibility that extreme but short-lived conditions may occur in the Gulf.

For the northern Gulf, reservoir ages were found to average $860 \pm 125 \mathrm{yr}$, whereas for the central Gulf, ages were younger on average ( $725 \pm 135 \mathrm{yr}$ ) (Table 2 ) and this difference is statistically significant ( $\mathrm{p}=0.04, t=2.31$, 2-tailed test with 17 d.f.). Part of the variability within each region is attributable to analytical error. To obtain the net variability, the variance $\left(\sigma^{2}\right)$ of the analytical error was subtracted from the total variance of $R$. This net variance was then converted to standard deviation units by taking the square root of the variance. The net variability (SD) of the reservoir ages for both the northern and central Gulf samples was found to be $110 \mathrm{yr}$. No temporal trends in the reservoir ages are apparent (Fig. 2). In particular, there is no apparent difference between samples collected prior to construction of the Hoover Dam (in the 1930s) and those collected subsequently. Neither do there seem to be consistent local patterns of deviation of reservoir ages: a wide range of reservoir ages occurs in multiple samples of various ages from both Puerto Peñasco (and nearby Cholla Bay) in the northern Gulf as well as for the Guaymas area in the central Gulf (Table 1).

TABLE 2. Gulf of California Radiocarbon Reservoir Ages (R) and Their Variability

\begin{tabular}{lrcccccc}
\hline Region & $N$ & $\begin{array}{c}\mathrm{R} \\
(\mathrm{yr})\end{array}$ & $\begin{array}{c}\text { SD of } \mathrm{R} \\
(\mathrm{yr})\end{array}$ & $\begin{array}{c}\text { net SD of } \mathrm{R} \\
(\mathrm{yr})^{*}\end{array}$ & $\begin{array}{c}\Delta \mathrm{R} \\
(\mathrm{yr})\end{array}$ & $\begin{array}{c}\mathrm{SD} \text { of } \Delta \mathrm{R} \\
(\mathrm{yr})\end{array}$ & $\begin{array}{c}\text { net SD of } \Delta \mathrm{R} \\
(\mathrm{yr})^{*}\end{array}$ \\
\hline Northern Gulf $\dagger$ & 7 & 861 & 125 & 109 & 538 & 108 & 89 \\
Central Gulf & 12 & 726 & 122 & 111 & 395 & 122 & 111 \\
\hline
\end{tabular}

*After subtraction of variation attributable to analytical error (see text for procedure). Mean analytical errors (1 $\sigma$ ) are $61 \mathrm{yr}$ for the northern Gulf samples and $50 \mathrm{yr}$ for the central Gulf samples.

†Shell from 1956 (Mod-14 and -16) not included in analysis.

Marine reservoir ages may vary over time because they are affected not only by contemporary atmospheric ${ }^{14} \mathrm{C}$ levels but also by the integrated history of atmospheric ${ }^{14} \mathrm{C}$ levels. For this reason, $\Delta \mathrm{R}$ values, representing the offset between a local marine reservoir age and the average worldwide reservoir age (based on models of exchange with atmospheric carbon; Stuiver, Pearson and Braziunas 1986), are usually used for calibrating marine ${ }^{14} \mathrm{C}$ dates. Thus a $\Delta \mathrm{R}$ value of 0 , for example, would characterize a sample that has a reservoir age typical for worldwide oceans. Except for the problematic 1956 shell discussed above, all Gulf samples show large, positive $\Delta \mathrm{R}$ values. For the northern Gulf, these average $540 \mathrm{yr}(\mathrm{SD}=110 \mathrm{yr})$; for the southern Gulf, they average $395 \mathrm{yr}(\mathrm{SD}=120 \mathrm{yr})$ (Table 2). Gulf of California samples thus show consistently higher ${ }^{14} \mathrm{C}$ reservoir ages, relative to the world oceans; and, on average, the northern Gulf samples show a reservoir age $150 \mathrm{yr}$ older than central Gulf samples. After removal of variation due to the average analytical error, the standard deviation is $90 \mathrm{yr}$ for the northern Gulf and $110 \mathrm{yr}$ for the central Gulf. Central Gulf samples thus show slightly higher variability of $\Delta \mathrm{R}$ values, despite having smaller reservoir ages.

We also determined the ${ }^{14} \mathrm{C}$ reservoir age of northern Gulf waters before the period represented by museum collections, by analysis of charcoal and shell from a midden in San Felipe, Baja California 


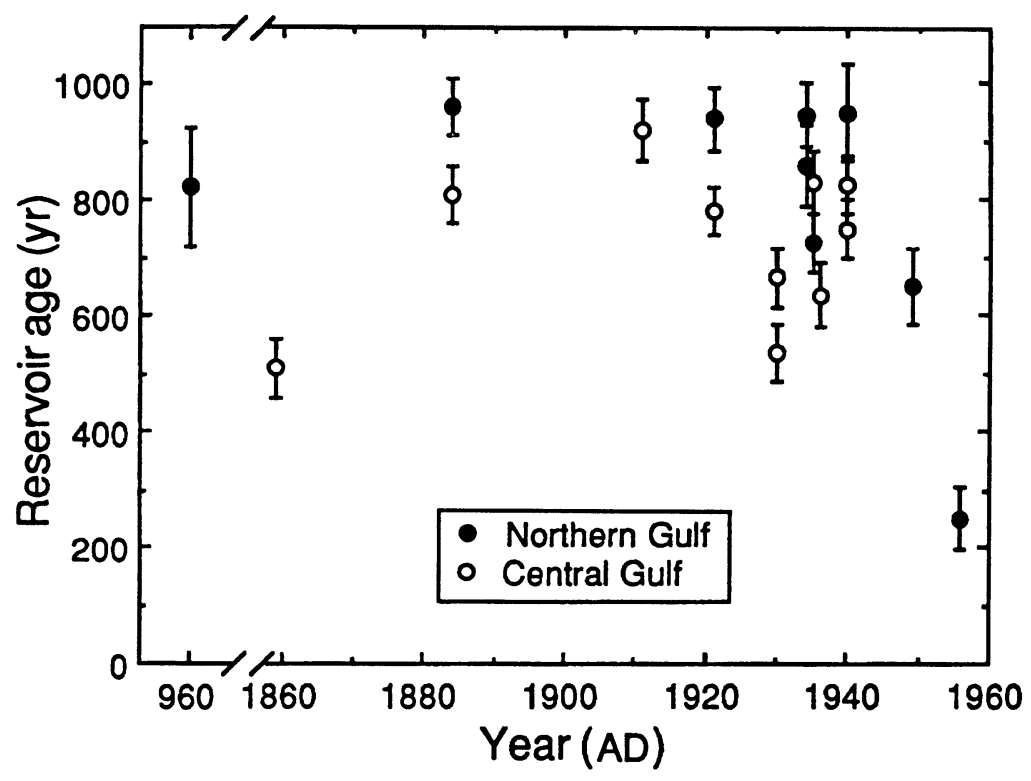

Fig. 2. Radiocarbon reservoir ages $(R)$ of mollusk samples from the northern and central Gulf of California, in relation to their year of collection. The AD 960 sample represents fossil material from a midden (see text). Error bars are $\pm 1 \sigma$.

(100 m SW of the lighthouse; SF-1, Fig. 1). Because the charcoal samples represent atmospheric ${ }^{14} \mathrm{C}$ levels at the time of growth of the wood and the interstratified shells generally are contemporary with the charcoal (but see below), the offset between marine and atmospheric ${ }^{14} \mathrm{C}$ values can be determined from ${ }^{14} \mathrm{C}$ analysis of the materials. This approach was used by Little (1993) to analyze variation in late Holocene marine reservoir ${ }^{14} \mathrm{C}$ ages around the New England region of the United States. Along the Baja California coast, there are few trees or shrubs. However, there is an abundant supply of driftwood, brought down by the Colorado River when it still flowed into the Gulf. Such driftwood may be the source of the charcoal found in the midden at San Felipe, located only a few hundred meters from the shore. Because some of the driftwood may have had a significant age at the time it was collected for firewood, we analyzed three charcoal samples from the midden to check for age variation. Results (Table 3 ) indicate that one of the three samples is significantly older than the others, but the two youngest ones are of analytically identical age (1075 \pm 50 and $1065 \pm 50 \mathrm{BP})$. We accept this age as representing the age of the midden and therefore also the ${ }^{14} \mathrm{C}$ activity of the atmo-

TABLE 3. Other Radiocarbon Dates

\begin{tabular}{|c|c|c|c|c|}
\hline $\begin{array}{l}\text { Sample } \\
\text { no. }\end{array}$ & Material & Site & Lab code & $\begin{array}{l}{ }^{14} \mathrm{C} \text { age } \\
\text { (yr BP) }\end{array}$ \\
\hline Mo-Col & Freshwater mussel* & $\begin{array}{l}\text { Colorado River, at } \\
\text { U.S.-Mexican border }\end{array}$ & AA-19662 & $1420 \pm 80$ \\
\hline SF-1 & Shell (Protothaca grata) & San Felipe midden & AA-17766 & $1885 \pm 90$ \\
\hline SF-1 & Charcoal & San Felipe midden & AA-17768 & $1220 \pm 50$ \\
\hline SF-1 & Charcoal & San Felipe midden & AA-17769 & $1075 \pm 50$ \\
\hline SF-1 & Charcoal & San Felipe midden & AA-17770 & $1065 \pm 50$ \\
\hline
\end{tabular}

*Anodonta dejecta; NMNH130171; collected March, 1894. 
sphere contemporary with the shells in the midden. Comparison of this charcoal ${ }^{14} \mathrm{C}$ age to that of a shell sample from the midden $(1885 \pm 90 \mathrm{BP})$ indicates a reservoir age (R) of $815 \pm 100 \mathrm{yr}$. This is well within the range of values determined in late 19th and early-to-middle 20th century samples from museum collections (Fig. 2) and suggests that more recent conditions in the Gulf are representative of conditions in the more distant past. Calibration of the two charcoal ${ }^{14} \mathrm{C}$ dates gives an age of $\mathrm{AD} 960$ for the midden.

\section{CAUSES OF LARGE RADIOCARBON RESERVOIR AGES IN THE GULF}

We consider here two possible sources of old carbon contributing to the large ${ }^{14} \mathrm{C}$ reservoir ages in the Gulf of California: input from the Colorado River flowing into the northern end of the Gulf and upwelling of deep Pacific water drawn up into the Gulf from the south.

In order to assess the possible contribution of old bicarbonate carbon from the Colorado River, we carried out ${ }^{14} \mathrm{C}$ analysis on shell carbonate of a freshwater mussel sample collected from the lower reaches of the river in the $1890 \mathrm{~s}$, before flow conditions of the river were altered. The apparent ${ }^{14} \mathrm{C}$ age of this sample is $1420 \mathrm{BP}$ (Table 3). In relation to atmospheric ${ }^{14} \mathrm{C}$ levels at that time (apparent age of $104 \mathrm{BP}$; Stuiver and Becker 1993), this sample shows a ${ }^{14} \mathrm{C}$ deficiency equivalent to $1315 \mathrm{yr}$. This is the result of the dissolution of limestone or the input of old groundwater along the river's course.

Using a simple mass balance approach, we can consider what proportion of river water of this apparent age would have to be mixed with Pacific surface waters in order to obtain the observed average reservoir ages of 860 and $725 \mathrm{yr}$ for the northern and central Gulf areas, respectively. For this purpose, the situation in AD 1880 is calculated, because this is around the time for which a Colorado River ${ }^{14} \mathrm{C}$ datum is available. Radiocarbon activity values $(A)$ were calculated from the model marine ${ }^{14} \mathrm{C}$ age for that time ( $480 \mathrm{yr}$; Stuiver and Braziunas 1993) and the $\Delta \mathrm{R}$ values for the northern and central Gulf (Table 2) and for Eastern Pacific surface waters around Mexico $(\Delta \mathrm{R}=185 \mathrm{yr}$; Stuiver, Pearson and Braziunas 1986). The $A$ values are 0.881 and 0.897 for the northern and central Gulf respectively, 0.921 for Pacific waters, and 0.838 for Colorado River water. Calculations yield an estimate of $48 \%$ for the proportion of bicarbonate carbon derived from the Colorado River for the northern Gulf and $29 \%$ for the central Gulf under this scenario. However, because bicarbonate concentrations in river water are low compared to the ocean, an even higher proportion of river water to Pacific water would be required to produce the estimated carbon proportions. In the 1950s, Colorado River water contained only $2.9 \mathrm{ppm}$ bicarbonate (Roden 1964) or about an order of magnitude less than typical ocean water. Hence a mixture of river and ocean water in which 48 to $29 \%$ of the bicarbonate was of river origin would have to be largely fresh water. In fact, both the northern and central Gulf regions are slightly hypersaline (35-36\%o; Roden 1964). Thus, water from the Colorado River cannot be the predominant source of the observed ${ }^{14} \mathrm{C}$ reservoir ages in the Gulf.

As a further test of the possible influence of the Colorado River on reservoir ages in the Gulf, we analyzed the stable isotope composition $\left({ }^{18} \mathrm{O} /{ }^{16} \mathrm{O}\right.$ and $\left.{ }^{13} \mathrm{C} /{ }^{12} \mathrm{C}\right)$ of the ${ }^{14} \mathrm{C}$-dated mollusk shells. Generally, river waters show $\delta^{18} \mathrm{O}$ values depleted in ${ }^{18} \mathrm{O}$ relative to marine waters, except where evaporative enrichment has occurred during the course of flow to the sea. River $\delta^{13} \mathrm{C}$ values also tend to be depleted in ${ }^{13} \mathrm{C}$, due to input of carbon from decomposition of terrestrial plant material. For conditions in the lower Colorado River prior to diversion, we turn to analysis of the 1894 freshwater mussel sample. Isotopic analysis gives a $\delta^{18} \mathrm{O}$ value of $-8.16 \%$ and a $\delta^{13} \mathrm{C}$ value of $-8.32 \%$. For comparison, a Chione shell collected alive from Vega Island in the northern Gulf in 1993 (when there was no flow from the Colorado River and thus representing a pure marine signal) gave $\delta^{18} \mathrm{O}=$ 
$-2.29 \%$ and $\delta^{13} \mathrm{C}=+0.07 \%$. If marine reservoir ages were significantly influenced by Colorado River flow, then it would be expected that higher reservoir ages would be associated with more negative $\delta^{18} \mathrm{O}$ and $\delta^{13} \mathrm{C}$ values. Results of isotopic analyses of our pre-bomb bivalve sample set are presented in relation to the ${ }^{14} \mathrm{C}$ reservoir ages of the specimens in Fig. 3. For both oxygen and carbon isotopes, no trend of isotope ratios in relation to reservoir ages is seen for either the northern or central Gulf samples. Also, mean stable isotope values are similar for both the northern and central Gulf, whereas one would expect more negative $\delta^{13} \mathrm{C}$ and $\delta^{18} \mathrm{O}$ values in the northern Gulf if Colorado River flow had a significant influence. Thus, the stable isotope results support the ${ }^{14} \mathrm{C}$ results in pointing to an insignificant influence of Colorado River flow on ${ }^{14} \mathrm{C}$ reservoir ages in the Gulf.

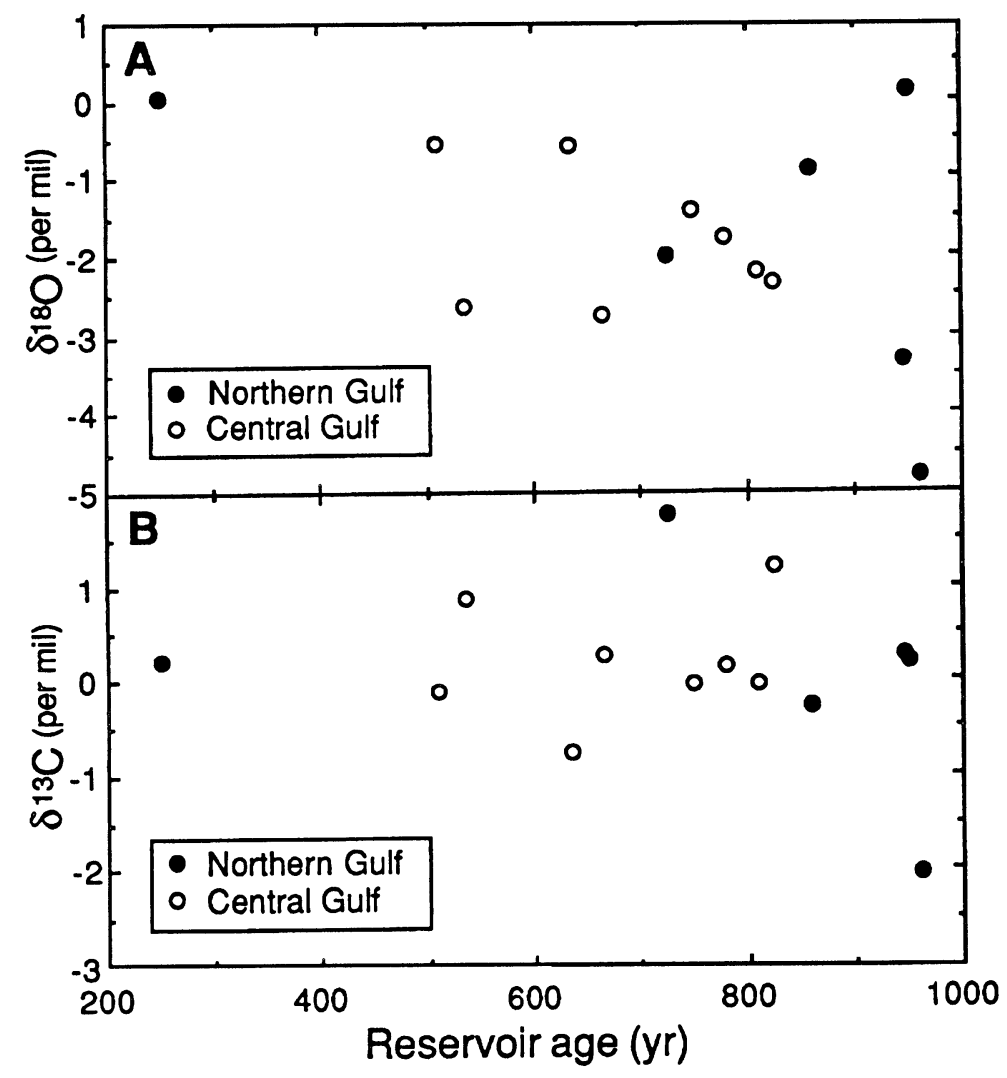

Fig. 3. Stable isotope composition of Gulf mollusks in relation to their radiocarbon reservoir ages. A. Oxygen isotope composition; B. Carbon isotope composition.

If the Colorado River has little or no effect on ${ }^{14} \mathrm{C}$ ages, then we infer that upwelling must be the predominant cause of the high reservoir ages observed in the Gulf. Water in the Pacific Ocean has an apparent age of $>2000 \mathrm{yr}$ at depths of $2000 \mathrm{~m}$ or more (Bien, Rakestraw and Suess 1963). The much smaller reservoir ages observed in the Gulf thus represent mixing of such old upwelling waters with surface waters that have been exchanging with atmospheric $\mathrm{CO}_{2}$. The ${ }^{14} \mathrm{C}$ results indicate that the effects of upwelling are more predominant in the northern Gulf than in the central Gulf. This could be the result of greater upwelling in the north. However, the larger tides in the north, resulting in greater mixing of surface waters with older deep water, could also be a factor. 


\section{Discussion}

The analyses presented above provide factors ( $\Delta R$ values) that can be used for correction of ${ }^{14} \mathrm{C}$ ages of fossil samples from the northern and central regions of the Gulf of California. It should be noted, however, that the standard deviations of these reservoir age corrections are rather large (90 to $120 \mathrm{yr}$; Table 2). This variability in reservoir ages limits the precision of age determination of marine samples in the area by ${ }^{14} \mathrm{C}$ analysis. Consideration of the additional error due to variability of the $\Delta \mathrm{R}$ values is provided for in the widely used ${ }^{14} \mathrm{C}$ calibration program CALIB 3.0 (Stuiver and Reimer 1993).

In only a few areas of the world oceans are there sufficient numbers of analyses of modern pre-bomb samples to reliably quantify the variability of $\Delta \mathrm{R}$ values. In southern Norway, variation of apparent ${ }^{14} \mathrm{C}$ ages of 11 samples (collected between 1898 and 1923) was found to be essentially the same as analytical error, thus indicating no detectable variation in reservoir ages (Mangerud and Gulliksen 1975). However, for the coastal waters of Denmark (excluding samples from fjords), analysis of 14 samples of mollusks (collected between 1885 and 1916) shows a variation (SD) in $\Delta \mathrm{R}$ values of 80 $\mathrm{yr}$ (Heier-Nielsen et al. 1995). After subtraction of the average analytical error (62 yr), a net residual variation of $51 \mathrm{yr}$ for $\Delta \mathrm{R}$ remains. Along the California coast (Bouey and Basgall 1991; data from Berger, Taylor and Libby 1966 and Robinson and Thompson 1981, compiled and analyzed by Stuiver, Pearson and Braziunas 1986), 14 samples (1878-1949) show a mean $\Delta R$ value of $355 \pm 193$ $\mathrm{yr}$; after removal of the average analytical error $(57 \mathrm{yr})$, the net variability of the reservoir ages is 185 yr. Analyses of 14 samples of northern and southern California coastal mollusk samples by Ingram and Southon (1997) show a similar mean $\Delta \mathrm{R}$ value (391 yr) but a slightly larger net variability $\left(252 \mathrm{yr}\right.$ ). Large temporal variations in ${ }^{14} \mathrm{C}$ reservoir ages have also been documented for the California coast, based on ${ }^{14} \mathrm{C}$ analysis of pteropod shells in varved sediments (Southon and Baumgartner 1996). Thus, the contribution of uncertainties in $\Delta R$ to the overall error of calibrated marine ${ }^{14} \mathrm{C}$ dates ranges from negligible in some situations (southern Norway) to other situations, such as the Gulf of California and the coast of California, in which the variability of $\Delta \mathrm{R}$ is considerably greater than the analytical error of the dated sample. Areas having high ${ }^{14} \mathrm{C}$ reservoir ages due to upwelling may also be expected to have higher variation in reservoir ages due to spatial and/or temporal variability in upwelling.

\section{ACKNOWLEDGMENTS}

We are indebted to the following natural history museum personnel for providing the samples upon which this study was based: M. G. Harasewych (NMNH), E. Kools (CASIZ), J. McLean and the late C. C. Coney (LACM), and R. Wetzer (SDNHM). We thank E. R. M. Druffel, W. Broecker, M. Stuiver, and an anonymous reviewer for helpful discussions and comments concerning this study. This research was supported by NSF grant EAR9405412 to Flessa and Goodfriend. This is C.E.A.M. contribution no. 27.

\section{REFERENCES}

Berger, R., Taylor, R. E. and Libby, W. F. 1966 Radiocarbon content of marine shells from the California and Mexican west coast. Science 153: 864-866.

Bien, G. S., Rakestraw, N. W. and Suess, H. E. 1963 Radiocarbon dating of deep water of the Pacific and Indian Ocean. Bulletin de l'Institut Océanographique de Monaco 61(1278): 1-16.

Bouey, P. D. and Basgall, M. E. 1991 Archaeological pat- terns along the south central coast, Point Piedras Blancas, San Luis Obispo County, California: Archaeological test evaluation of sites CA-SLO-264, SLO-266, SLO-267, SLO-268, SLO-1226, and SLO-1227. California Dept. of Transportation, rep. no. 05-SLO-1. Reprint by Coyote Press, Salinas, California.

Druffel, E. M. 1987 Bomb radiocarbon in the Pacific: Annual and seasonal timescale variations. Journal of 
Marine Research 45: 667-698.

Druffel, E. R. M. 1997 Post-bomb radiocarbon records of surface corals from the tropical Atlantic Ocean. Radiocarbon 38: 563-572.

Flessa, K. W., Cutler, A. H. and Meldahl, K. H. 1993 Time and taphonomy: Quantitative estimates of timeaveraging and stratigraphic disorder in a shallow marine habitat. Paleobiology 19: 266-286.

Fradkin, P. L. 1984 A River No More: The Colorado River and the West. Tucson, University of Arizona Press: $360 \mathrm{p}$.

Heier-Nielsen, S., Heinemeier, J., Nielsen, H. L and Rud, N. 1995 Recent reservoir ages for Danish fjords and marine waters. Radiocarbon 37: 875-882.

Hubbs, C. L., Bien, G. S. and Suess, H. E. 1965 La Jolla natural radiocarbon measurements IV. Radiocarbon 7: 66-117.

Ingram, B. L. and Southon, J. R. 1997 Reservoir ages in eastern Pacific coastal and estuarine waters. Radiocarbon 38(3): 573-582.

Keith, M. L., Anderson, G. M., and Eichler, R. 1964 Carbon and oxygen isotopic composition of mollusk shells from marine and fresh-water environments. Geochimica et Cosmochimica Acta 28: 1757-1786.

Little, E. A. 1993 Radiocarbon age calibration at archaeological sites of coastal Massachusetts and vicinity. Journal of Archaeological Science 20: 457-471.

Mangerud, J. and Gulliksen, S. 1975 Apparent radiocarbon ages of recent marine shells from Norway, Spitsbergen, and Arctic Canada. Quaternary Research 5: 263-273.

Robinson, S. W. and Thompson, G. 1981 Radiocarbon corrections for marine shell dates with application to southern Pacific Northwest Coast prehistory. Syesis 14: 45-57.

Roden, G. I. 1964 Oceanographic aspects of Gulf of California. In van Andel, T. H. and Shor, G. G., Jr., eds., Marine Geology of the Gulf of California. Tulsa,
American Association of Petroleum Geologists: 30 58.

Southon, J. R. and Baumgartner, T. A. 1996 A long-term record of upwelling from the Santa Barbara Basin, southern California. Abstracts of the 7th International AMS Conference. Radiocarbon 38(1): 114

Steinbeck, J. 1986 The Log from the Sea of Cortez. 1951. Reprint, New York, Penguin Books: 282 p.

Stuiver, M. and Becker, B. 1993 High-precision decadal calibration of the radiocarbon time scale, AD 1950 6000 BC. In Stuiver, M., Long, A. and Kra, R. S., eds., Calibration 1993. Radiocarbon 35(1): 35-65.

Stuiver, M. and Braziunas, T. F. 1993 Modeling atmospheric ${ }^{14} \mathrm{C}$ influences and ${ }^{14} \mathrm{C}$ ages of marine samples to 10,000 BC. In Stuiver, M., Long, A. and Kra, R. S., eds., Calibration 1993. Radiocarbon 35(1): 137-189.

Stuiver, M. and Reimer, P. J. 1993 Extended ${ }^{14} \mathrm{C}$ data base and revised CALIB $3.0{ }^{14} \mathrm{C}$ age calibration program. In Stuiver, M., Long, A. and Kra, R. S., eds., Calibration 1993. Radiocarbon 35(1): 215-230.

Stuiver, M. Pearson, G. W. and Braziunas, T. F. 1986 Radiocarbon age calibration of marine samples back to 9000 cal yr BP. In Stuiver, M. and Kra, R. S., eds., Proceedings of the 12 th International ${ }^{14} \mathrm{C}$ Conference, $\mathrm{Ra}$ diocarbon 28(2B): 980-1021.

Taylor, R. E. and Berger, R. 1967 Radiocarbon content of marine shells from the Pacific coasts of Central and South America. Science 158: 1180-1182.

Thompson, R. W. 1968 Tidal Flat Sedimentation on the Colorado River Delta, Northwestern Gulf of California. Geological Society of America Memoir 107 Boulder, Colorado, Geological Society of America: $133 \mathrm{p}$.

Weidman, C. R. and Jones, G. A. 1993 A shell-derived time history of bomb ${ }^{14} \mathrm{C}$ on Georges Bank and its Labrador Sea implications. Journal of Geophysical Research 98(C8): 14,577-14,588. 